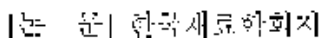

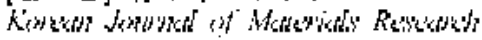

Vol. $16 . \mathrm{No} 11(2006)$

\title{
$\mathrm{Al}$ 고압주조공법에서 사출슬리브 온도 조절을 봉한 Chill layer의 최적 제어
}

\author{
박진엉 ${ }^{\dagger}$ 김억술 , 박용호 - 박익 닌

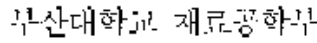

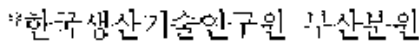

\section{Optimal Control of Chill layers through Regulation of Temperature on Shot Sleeve in Aluminum High Pressure Diecasting}

\author{
Jin-Young Park ${ }^{\dagger}$, Eok-Soo Kim; Yong-Ho Park and Ik-Min Park \\ Dept. of Material Engineering, Pusan National University \\ *Pusan R\&D Center; Korea Institute of Industrial Technology

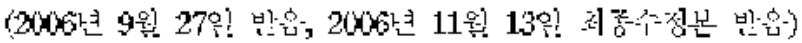

\begin{abstract}
In this study, the effect of chill lavers oocured in shot sleve on the molten metal filling was analyzed though computer simulation. The behavion of chill layess with temperature variation of shot aleve wet from 200 to $280^{\circ} \mathrm{C}$ was also investigated. The simulation results showed the chill lavers set in the in-gates: during the injection prosess change the main filling dinection and cause turbulent flow lattem. resultimg in powsities mide the castings. The amount of chill lavers with the incossing temperature of shot sleve was considerably reduoed. Particularly, at the wtting temperature of $280^{\circ} \mathrm{C}$ by heat oontrol unit- the biggest. reduction in chill layens exollent trimmed surfae and the highest density were achieved. suggesting that as the optimal sleve ondition in alumimum high pressure diecasting evejpeially for highly omplex parts like valpe body.
\end{abstract}

Key words Aluminum diecasting. Chill-laver: Heat contiol unit. Filling simulation.

\section{1. 서 론}

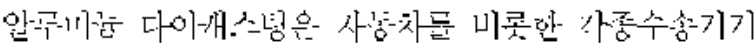
의 경량화 츧세에 1ㅡㄱ합하여 Al의 경량화 후ㄱㅘㅘㅇㅘ 다이개

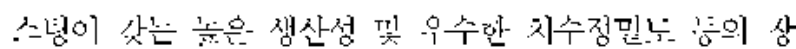
정으곤 산수록 적영 에가 긍가하고 있다. 다이개스녕 공 법은 사촌시 공기의 혼입에 따폰 기곡반생 낓 응고시 국

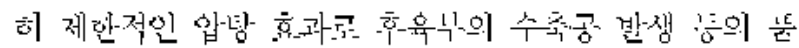
진 문제접을 안고 있어 77 적영이 단순 구좆재에 제한 비어 왔으나 최근에는 신공시스뎁의 반전과 국긱가압공

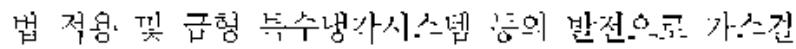
함에 의한 뚠진 문제룰 해건하여 기곤의 줌력줃존 낓 지 압조족에 의한 주존툰의 대체 정영이 흔어나.그 있는 츨

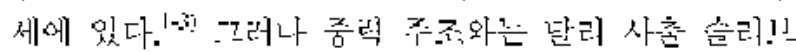
에 영당을 주당한 훙 츨던져 딬에 의해 사촌하는 다이

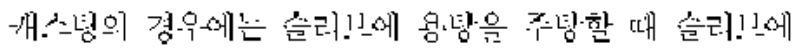
접촉하는 최혹영낭이 응고뇌는 과정에서 chill bayer가 형

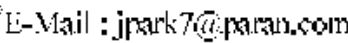

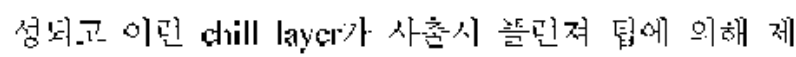

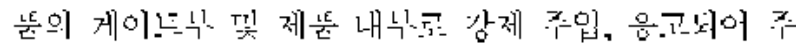

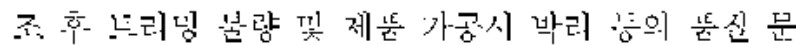
제룬 일으히는 것으옥 않려져 있다.+7! 이러한 chill layes 의 제뚠내 혼입윽 막기 위해서 일닉 선신업체룬 줌십오 고 Comb 게이느룰ㄹ 적영하거나 세라믹과 굽:숙윽 긱합 쿠

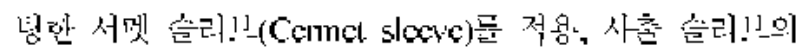

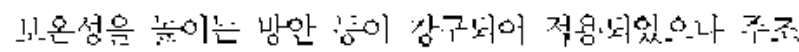

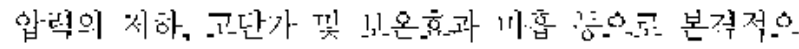
고 상영화는 디지 돗한 신정이다. 튼히 단순 구즌재가 아 넌 고내압 기민성을 오하는 고기흥성 닉눈의 다이개스녕 주종에 있어서 이러한 chill lay아가 제뚠의 주근성 낓 내 늑뚠진에 끼치는 영행에 대한 체계전인 연구는 따홉한 신 정이다. 따라서 본 연강에서는 녹은 내국눈진 수군을 오 하는 고기능성 제뚠을 중십오공 영 당 굽당시 반생하는 chill layer가 죽조성에 끼치는 영항윽 분식하고 그에 따 라 사촌 슬리니의 온눈룬 전전히 변화시켜 온눈변화에 따

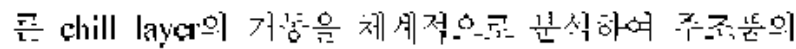

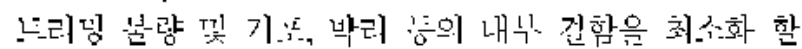


수 있는 최적의 사출 슬리브 관리 조건을 설정하는데 기 초 자료를 제공하고자 하였다.

\section{2. 실험 방법}

\subsection{Chill layer가 용탕 충전에 미치는 영향 해석} 사출 슬리브에서 형성된 chill layer가 폴런져 팁에 의 해 강제 유입되어 제품의 용탕 충전에 미치는 영향을 알 아보기 위해 컴퓨터 충전해석을 실시하였다. 해석에 사 용한 소프트웨어는 주조해석 전용 코드인 MAGMAsoft (Vr.4.2 SR2)를 사용하였으며 해석 대상 제품은 자동차 오토 밸브 바디(Auto Valve Body)로서 오토 트랜스미션 의 유압제어 부품으로 매우 복잡한 유로 및 두꺼운 두 께의 형상을 갖고 높은 내압기밀성과 주조 후 밸브 조 립을 위해 몸체에 많은 홀 가공이 이루어지는 것을 특징 으로 한다. Fig. 1에 본 연구 대상 제품과 주조방안의 모 델링을 나타내었다. 해석은 주조시 제품부(cavity)로 용탕 이 유입되는 게이트 부에 chill layer가 형성되지 않고 충 전되는 경우(Case 1)와 게이트부에 chill layer가 형성되어 있는 경우(Case 2)로 나누어서 해석을 진행하였다. Case 2 경우의 모델링을 작업에 있어서 chill layer의 형상과 크 기는 게이트부에 chill layer가 형성되어 있는 실 주조품 의 경우를 반영하였으며 Fig. 2에 각 경우에 대한 모델 링 결과와 Case2의 모델이 된 실주조품(Fig. 2(c))을 나 타내었다. 실제로 사출 슬리브에 형성된 chill layer가 Case 2 의 가정처럼 용탕의 충전 전 $100 \%$ 게이트에 걸 쳐있는 상태에서 충전이 이루어진다고 가정할 수는 없자 만 chill layer가 게이트에 형성될 때 이미 제품부 내에 충전된 용탕량에 상관없이 용탕 충전 완료시까지 영향을 미칠 것으로 사료되는 바 Case 2에 대한 충전해석은 용

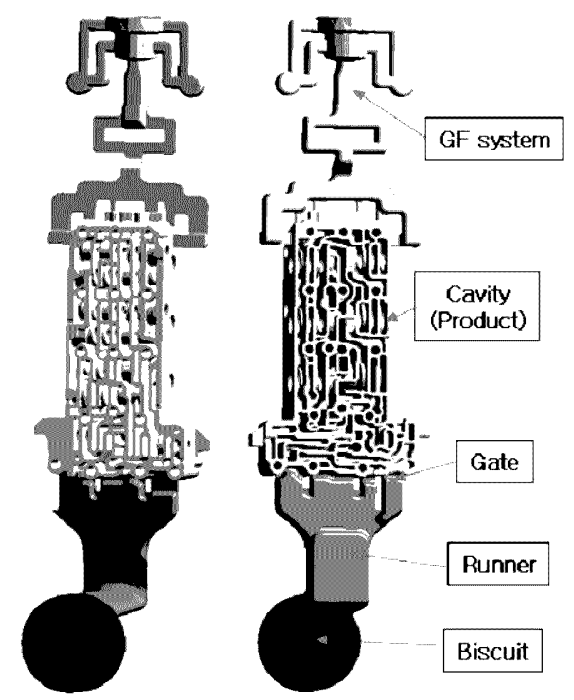

Fig. 1. Solid modeling of casting system for Auto transmission Valve body.

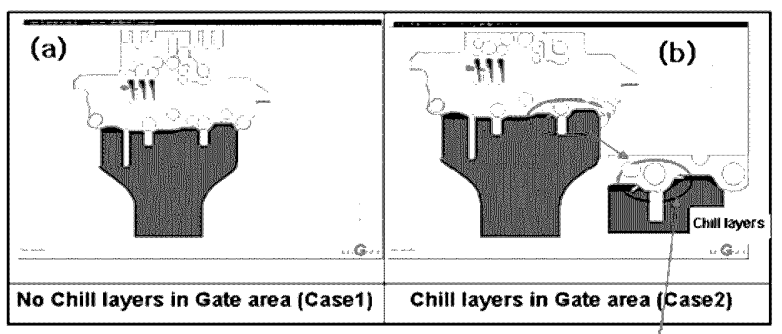

(c)

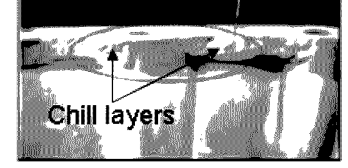

Fig. 2. Solid modeling of (a) Case 1 and (b) Case 2 conditon. (c) As-diecasted and trimmed sample with chill layers occurred in gate area.

Table 1. Simulation condition.

\begin{tabular}{|c|c|c|c|}
\hline \multicolumn{2}{|c|}{ Classification } & Case 1 & Case 2 \\
\hline \multicolumn{2}{|c|}{ Material } & ALDC 8 & ALDC 8 \\
\hline \multicolumn{2}{|c|}{ Pouring temp. } & $660^{\circ} \mathrm{C}$ & $660^{\circ} \mathrm{C}$ \\
\hline \multirow{2}{*}{ Velocity } & Low & $0.25 \mathrm{~m} / \mathrm{s}$ & $0.25 \mathrm{~m} / \mathrm{s}$ \\
\hline & High & $2.7 \mathrm{~m} / \mathrm{s}$ & $2.7 \mathrm{~m} / \mathrm{s}$ \\
\hline \multicolumn{2}{|c|}{ Casting pressure } & $1150 \mathrm{kgf} / \mathrm{cm}^{2}$ & $1150 \mathrm{kgf} / \mathrm{cm}^{2}$ \\
\hline Chill & Material & - & ALDC 8 \\
\hline layer & Temp. & - & $480^{\circ} \mathrm{C}$ \\
\hline \multicolumn{2}{|c|}{ Number of mesh } & $25,000,000$ & $30,000,000$ \\
\hline
\end{tabular}

탕 충전 방향, 흐름상태, 기포발생량 등 chill layer가용탕 충전에 미치는 영향을 알아보는 데 중요하다 판단된다. 각 해석 경우에 대한 해석 조건을 Table 1에 요약하였다.

\section{2 사출 슬리브 온도 변화에 따른 chill layer의 거 동 실험}

사출 슬리브에서의 온도 변화에 따른 chill layer의 거 동을 평가하기 위해 사출 슬리브에 가열, 냉각을 위한 유 로(Oil Channel)를 설계, 제작하였다. 사출 슬리브는 SKD61 재질로 직경 $\varnothing 80$, 길이 $660 \mathrm{~mm}$ 의 일체형 슬 리브를 적용하였으며 주조기는 TOSHIBA $800 \mathrm{Ton}(\mathrm{CL}$ type)을 적용하였다. Fig. 3에 사출 슬리브 시스템과 실 험장치의 개략도를 나타내었다. 사출 슬리브 하부의 양 편측에 각각 3 개의 채널을 길이 방향으로 설치하였고 끝 단부에는 링 타입의 채널을 설치하였다. 유로를 설치한 사출 슬리브에 온도 조절기(Max. Temp. $300^{\circ} \mathrm{C}$, Capa. $6 \mathrm{~kW}$ for heating, $70 \mathrm{~kW}$ for cooling)를 내열 호스를 통해 연결하였고 슬리브 온도 조절용 오일은 특수 고온 용 합성유(Therminnol 66)를 사용하였다. 또 각 실험 조 건에 따른 슬리브의 온도 측정을 위해 Fig. 3 와 같이 사 출 슬리브에 열전대를 슬리브의 용탕 주입 직하부(T1), 기 


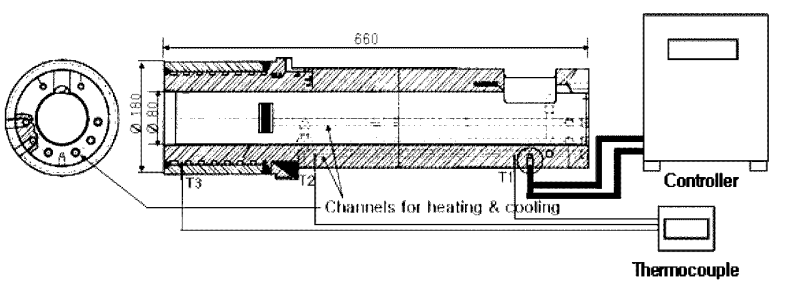

Fig. 3. Schematic drawing of experimental setup.

계 플래턴 삽입부(T2) 그리고 금형 슬리브와 만나는 부위 (T3)에 각각 장착 한 후 온도 기록계(Yokogawa SR1000) 에 연결하여 온도를 연속 측정하였다.

사출 슬리브의 온도 변화는 온도 조절기를 적용하지 않 은 경우를 포함해서 온도 조절기 설정온도를 200,250 , $280^{\circ} \mathrm{C}$ 로 변화시켜 가며 조건 당 30 개씩 시험 주조하였 으며 설정 온도 변경시 마다 온도 안정화를 위해 10 개 씩 주조 후 시험 주조하였다. 각 조건에 따른 실험 결 과 분석을 위해 각 조건에 따른 샘플의 비스켓을 절단 하여 chill layer의 형성량을 비교하고 또 제품의 게이트 부를 절단하여 절단부의 조직과 트리밍 파면을 관찰하였 다. 아울러 각 조건에 따른 제품의 기공도를 밀도계 (Densimeter, SD120L)를 이용하여 밀도를 측정하여 상호 비교 하였다.

\section{3. 결과 및 고찰}

3.1 Chill layer가 용탕 충전에 미치는 영향 해석 결과 게이트부에 chill layer가 없는 경우(Case 1)와 존재하
는 경우(Case 2)에 대한 용탕 충전해석 결과를 Fig. 4에 나타내었다. Case 1과 Case 2의 경우 충전시간은 동일 하였고 충전 완료시까지 용탕온도가 액상선 이하로 떨어 지지 않는 양호한 충전거동을 나타내었다. 그러나, $40 \%$ 충전시 Case 1의 chill layer가 없는 경우에는 탕흐름의 주방향이 직진하며 또 전체적으로 균일하게 충전되는 반 면 chill layer가 형성되어 있는 Case 2 의 경우에서는 탕 흐름의 주방향이 한쪽으로 치우쳐 충전되고 전체적인 충 전 양상도Case 1에 비해 불균일한 것으로 나타났다. 특 히, $60 \%$ 충전상태에서 Case 2의 경우가 상대적으로 제 품의 가장자리가 먼저 충전되는 속도가 커서 제품 중심 부에 가스고립(Air entrap)현상이 두드러자는 것으로 나 타났다. 이와 같이 Case 2의 용탕 충전 방향이 Case 1 에 비해 바뀐 것은 게이트에 걸쳐진 chill layer의 형상 이 일정치 않고 게이트 입구 정방향에서 비스듬하게 놓 여 있어 고속으로 충전하는 용탕의 흐름을 순간적으로 chill layer의 방향으로 변경시키기 때문인 것으로 판단된 다. MAGMAsoft의 기포결함 예측 도구인 Air pressure criteria를 이용하여 $100 \%$ 충전완료 후의 압력 분포 결과 를 Fig. 5에 나타내었다. 예상한 바와 같이 Case 2의 경 우에서 충전 거동시 와류가 나타난 부위를 중심으로 더 높은 압력분포를 나타내 기포결함 가능성이 전반적으로 높 은 것으로 나타났으며 특히 chill layer가 존재하는 부위 에서는 새로이 기포 결함이 생성될 가능성이 높아졌다. Case 2의 경우에서 기포 결함 가능성이 상대적으로 Case 1 보다 높아진 것은 충전 해석 결과 용탕의 충전 양상 이 Case 1에 비해 전체적으로 불균일하여 그로 인한 용

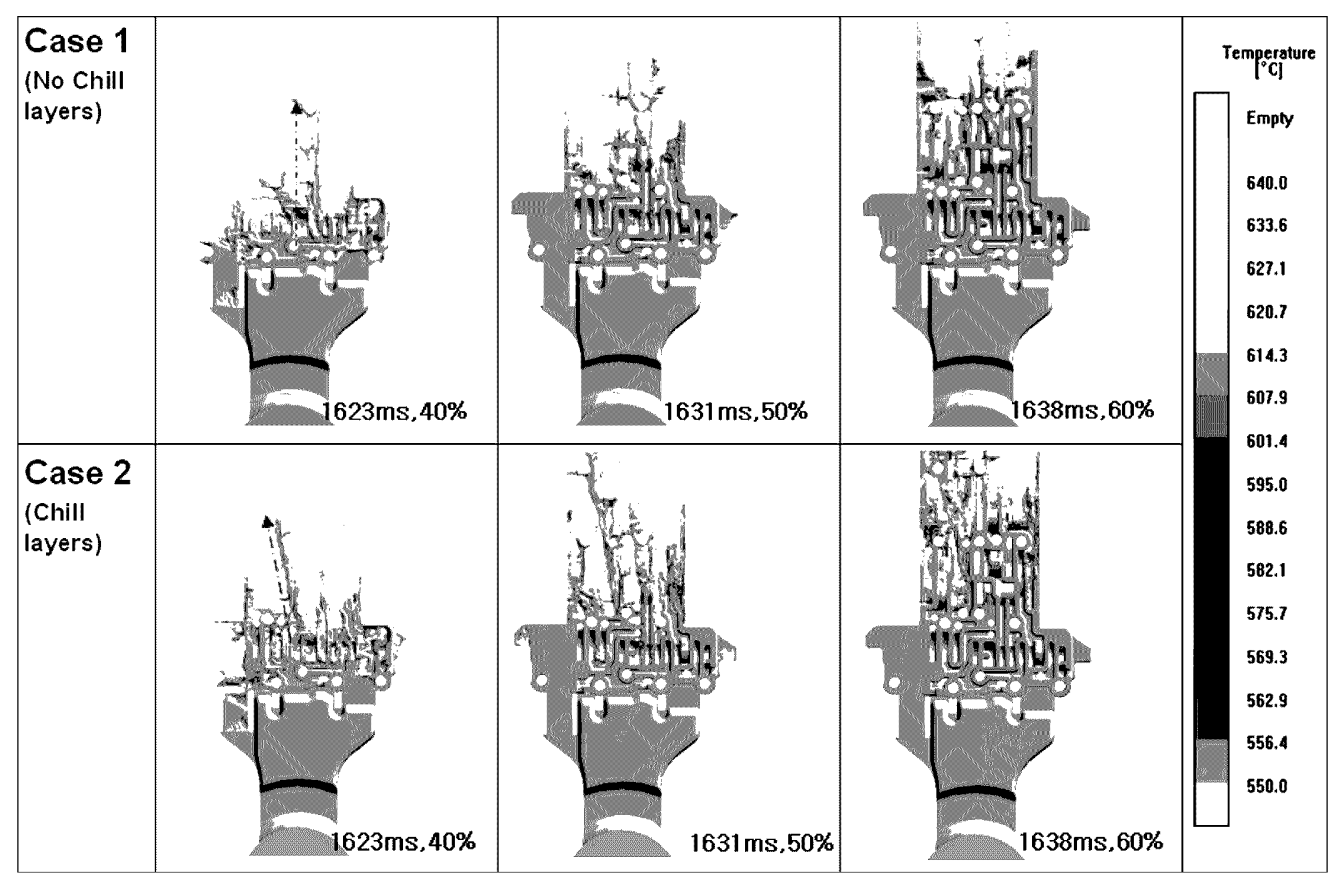

Fig. 4. Comparison of filling simulation results of Case 1 and Case 2. 

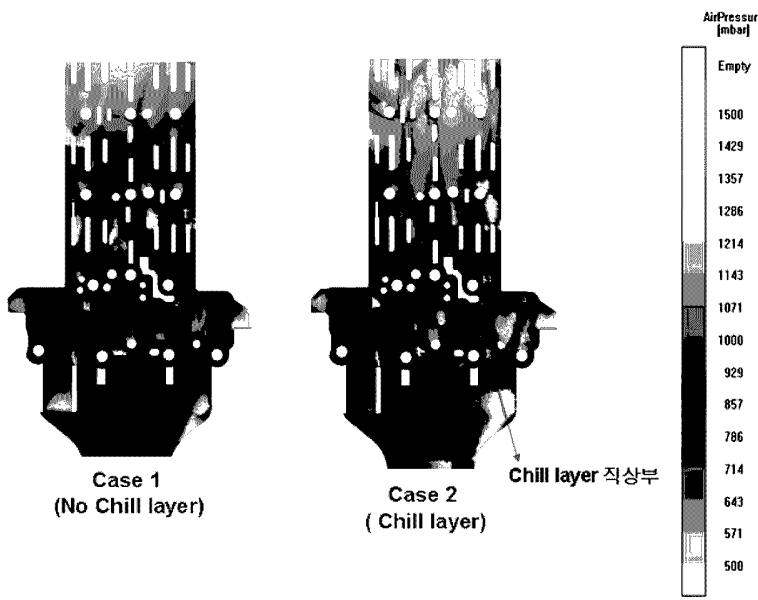

Fig. 5. Porosity possibility after $100 \%$ filled by air pressure criteria.

탕의 와류로 인한 가스의 함유 가능성이 높아졌기 때문 으로 여겨진다. 전술한 바와 같이 사출시 슬리브에서 형 성된 chill layer가 실주조품의 chill layer의 형상을 모 델링하여 해석한 결과라 할지라도 Case 2에서 가정한 바 와 같이 반드시 사출 전 게이트에 chill layer가 먼저 게 이트를 막고 있는 상태에서 사출이 진행된다고는 할 수 없다. 그러나 본 충전해석 결과를 통해서 Fig. 8의 비 스켓에 형성된 chill layer의 형상이 Fig. 6의 T1부의 비 교적 용탕의 온도 저하가 적은 슬리브 용탕 주입구 직 하부에서 형성되었음에도 불구하고 그 수량이 많고 형 상이 비교적 긴 것으로 판단할 때, Fig. 6의 T2부의 용 탕의 온도 저하가 심한 사출시 초기에 주입되는 용탕을 통해 유입되는 chill layer의 수량은 $\mathrm{T} 1$ 부에 비해 훨씬 많고 길이 또한 더욱 길어 cavity 충전 중 본 해석에서 가정한 경우처럼 충전 중 chill layer가 용탕의 흐름을 방해하여 기포 발생 가능성이 높아진다고 판단된다. 이 러한 해석 결과는 chill layer의 생성이 단순히 주조품 의 트리밍 작업시 chill layer 파단으로 인한 치수 불량 뿐 아니라 충전시 용탕의 탕흐름에 큰 영향을 미쳐 내 부 결함에 큰 영향을 미치는 중요한 요소로 작용한다고 판단할 수 있으며 특히 본 과제의 밸브바디와 같은 복 잡한 형상을 갖는 제품에서는 제품의 게이트부와 유로 부에 chill layer가 사출시 걸쳐있을 가능성이 상대적으 로 높아서 이로 인한 탕흐름을 방해할 가능성이 더욱 높 아 chill layer의 형성 방지를 위한 근본적인 조치가 더 욱 필요하리라 생각된다.

\section{2 사출 슬리브 온도 변화에 따른 파단칠층의 거 동 실험 결과}

사출슬리브에 온도 조절기를 적용하자 않은 경우와 온 도 조절기 설정 온도를 $200,250,280^{\circ} \mathrm{C}$ 로 설정하면서 공

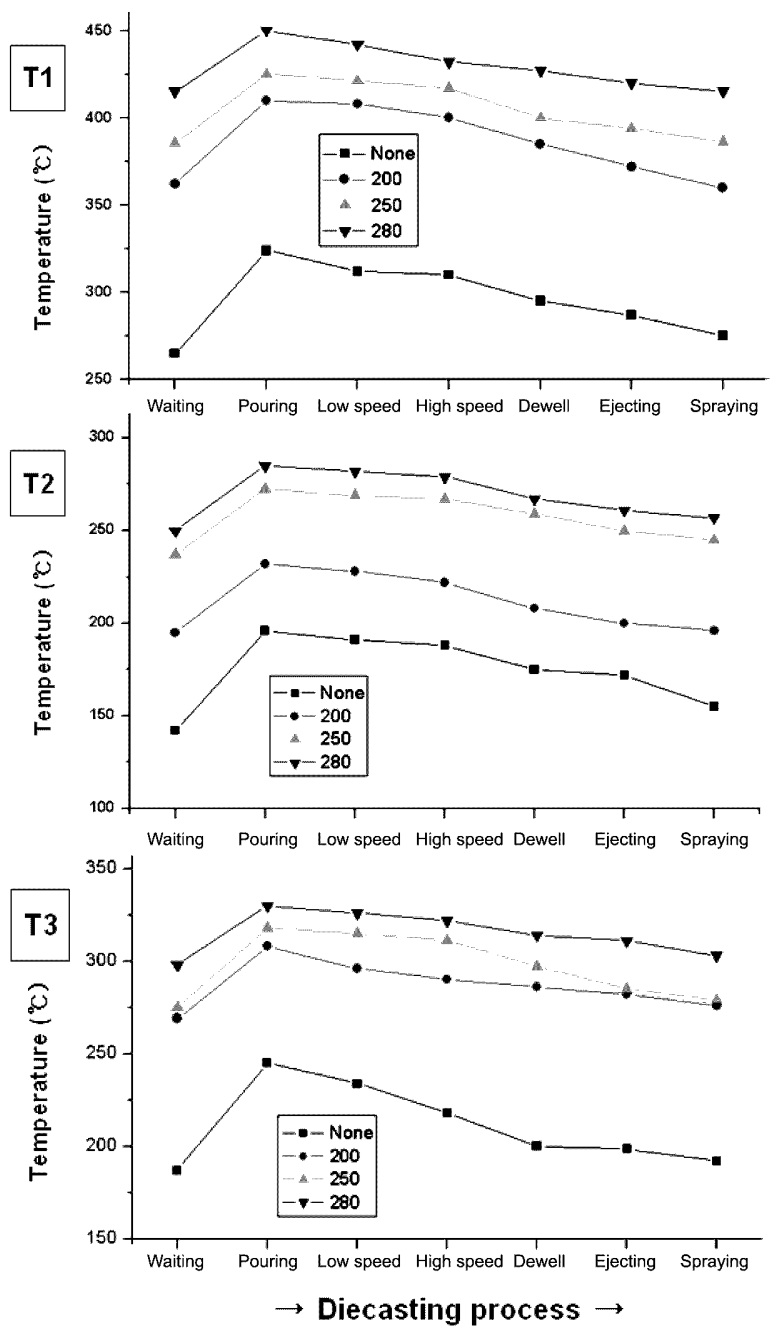

Fig. 6. Temperature profile at $\mathrm{T} 1, \mathrm{~T} 2$ and $\mathrm{T} 3$ during diecasting process with the variation of temperature on shot sleeve.

정 중에 얻은 온도 변화를 Fig. 6에 나타내었다. 먼저, 온 도 조절기를 적용하지 않은 경우 용탕 주입구 직하부의 온도인 $\mathrm{T} 1$ 의 온도가 용탕 주입공정에서 $325^{\circ} \mathrm{C}$, 용탕 대 기에서 $265^{\circ} \mathrm{C}$ 로 전 공정 구간에서 다른 $\mathrm{T} 2, \mathrm{~T} 3$ 부 보다 높은 온도 값을 나타냈고 기계 플래턴 삽입부인 $\mathrm{T} 2$ 의 온 도 용탕 주입공정에서 $196^{\circ} \mathrm{C}$, 용탕 대기상태에서 $142^{\circ} \mathrm{C}$ 를 나타내 전 공정 중 가장 낮은 값을 보였으며, 금형 슬리브와 만나는 지점인 $\mathrm{T} 3$ 의 온도는 각각 $243^{\circ} \mathrm{C}$ 및 $187^{\circ} \mathrm{C}$ 인 것으로 나타났다. 용탕 주입 및 대기 상태에서 $\mathrm{T} 2, \mathrm{~T} 3$ 의 온도가 $\mathrm{T} 1$ 부에 비해 현저히 낮았고 특히 $\mathrm{T} 2$ 부 에서는 $\mathrm{T} 1$ 부에 비해 $120^{\circ} \mathrm{C}$ 이상 차이를 보여 사출 슬리 브에 용탕을 주입할 때 $\mathrm{T} 2$ 부를 중심으로 $\mathrm{T} 3$ 부에서 chill layer가 집중적으로 많이 생성될 것으로 판단된다. 이는 앞 서 행한 충전해석에서 용탕 충전 초기 단계에서 chill layer가 용탕과 함께 유입되어 게이트 간섭을 일으킬 가 능성이 높다는 사출 해석 조건의 가정과 일치한다. 슬리 
브 온도를 $200^{\circ} \mathrm{C}$ 로 올렸을 경우 $\mathrm{T} 1$ 부의 온도는 $410^{\circ} \mathrm{C}$, $\mathrm{T} 2$ 부에서 $230^{\circ} \mathrm{C}$ 로 나타났다. 또 가장 높은 설정 온도인 $280^{\circ} \mathrm{C}$ 로 설정 한 경우에는 역시 $\mathrm{T} 1$ 부의 용탕 주입상태 에서 $450^{\circ} \mathrm{C}, \mathrm{T} 2$ 의 용탕 대기상태에서 $250^{\circ} \mathrm{C}$ 를 나타내었 다. 온도 조절기를 적용하지 않은 경우 공정상 온도 편 차는 약 $60^{\circ} \mathrm{C}$ 였으며 대체적으로 온도 조절기 설정 온도 가 높아질수록 편차 값이 줄어들어 $280^{\circ} \mathrm{C}$ 설정시는 약 $35^{\circ} \mathrm{C}$ 로 나타나 온도 조절기의 항온 효과가 나타난 것으 로 판단되었다.

슬리브에서 선행 응고된 chill layer는 사출시 제품 내 부로 유입되어 유로부와 같은 형상에 걸쳐 있다가 후속 충전되는 용탕과 만나 응고되면서 미세한 응고 층을 형 성하게 된다. 이러한 사출시 형성된 응고층은 제품 가공 시 박리 불량을 일으키게 된다. Fig. 7에 제품 가공시 chill layer에 기인한 박리 불량 현상을 나타내었다. Fig. 8 에는 슬리브 온도변화에 따라 얻은 샘플의 비스켓을 절 단하여 조직을 관찰한 사진을 나타내었다. Fig. 8(a)의 온 도 조절기를 적용하지 않은 경우 비스켓 중심부와 탕도 등에 전체적으로 chill layer가 다량 분포하고 있고 chill layer의 개별 크기도 비교적 큰 것으로 파악되었다. 그러 나 Fig. 8의 (b), (c), (d)의 경우에서 보는 바와 같이 사출 슬리브 적용 온도를 $200,250,280^{\circ} \mathrm{C}$ 로 증가시킴에 따라 비스켓부의 chill layer의 생성 수량이 감소하였고 $280^{\circ} \mathrm{C}$ 의 경우에서는 chill layer의 발생 수량 감소뿐 아니라 개 별 chill layer의 크기도 비교적 작은 것으로 나타났다.

각 사출 슬리브 온도 설정 조건에 따른 주조품의 품 질을 확인하기 위해서 Fig. 9의 모식도와 같이 제품의 게이트부를 절단하고 다시 게이트 중심선인 A-A면으로

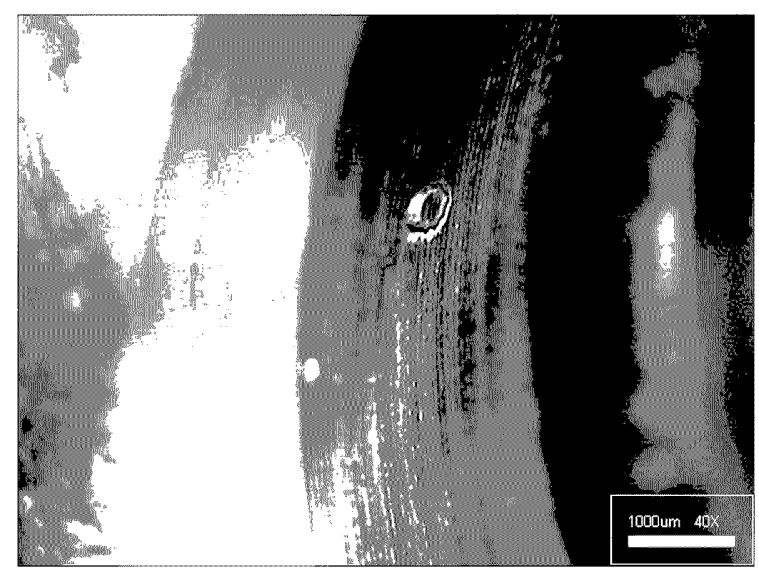

Fig. 7. Lamination defect caused by chill layer after machining.

절단하여 조직을 관찰하였다. Fig. 9(a)의 온도 조절기를 사용하자 않은 경우와 $280^{\circ} \mathrm{C}$ 설정한 경우와 비교할 때 온도 조절기를 적용하자 않은 경우에서 역시 chill layer 의 파단 잔류물이 많이 형성되는 것으로 나타났으며 또 트리밍 면의 거칠기도 $280^{\circ} \mathrm{C}$ 설정한 경우에서 보다 상 당히 거친 것으로 나타났다. 또 온도 조절기를 적용하지 않은 경우에서는 트리밍 파단면에 화살표시와 같은 크랙 이 발견되었는데 이러한 크랙은 제품의 강성 저하나 기 밀 불량 등 영향을 줄 수 있는 것으로 판단된다. (a)에 서 트리밍 파단면이 거칠고 또 크랙이 유발되는 곳에 chill layer의 파면이 존재하는 것을 확인할 수 있는 데 이런 chill layer가 사출 시 게이트에 존재하여 응고 경계층을 이루고 있다가 트리밍시 쉽게 분리되어 트리밍 공정 중 치수 불량을 유발하거나 또 크랙을 유발하는 원인으로 작
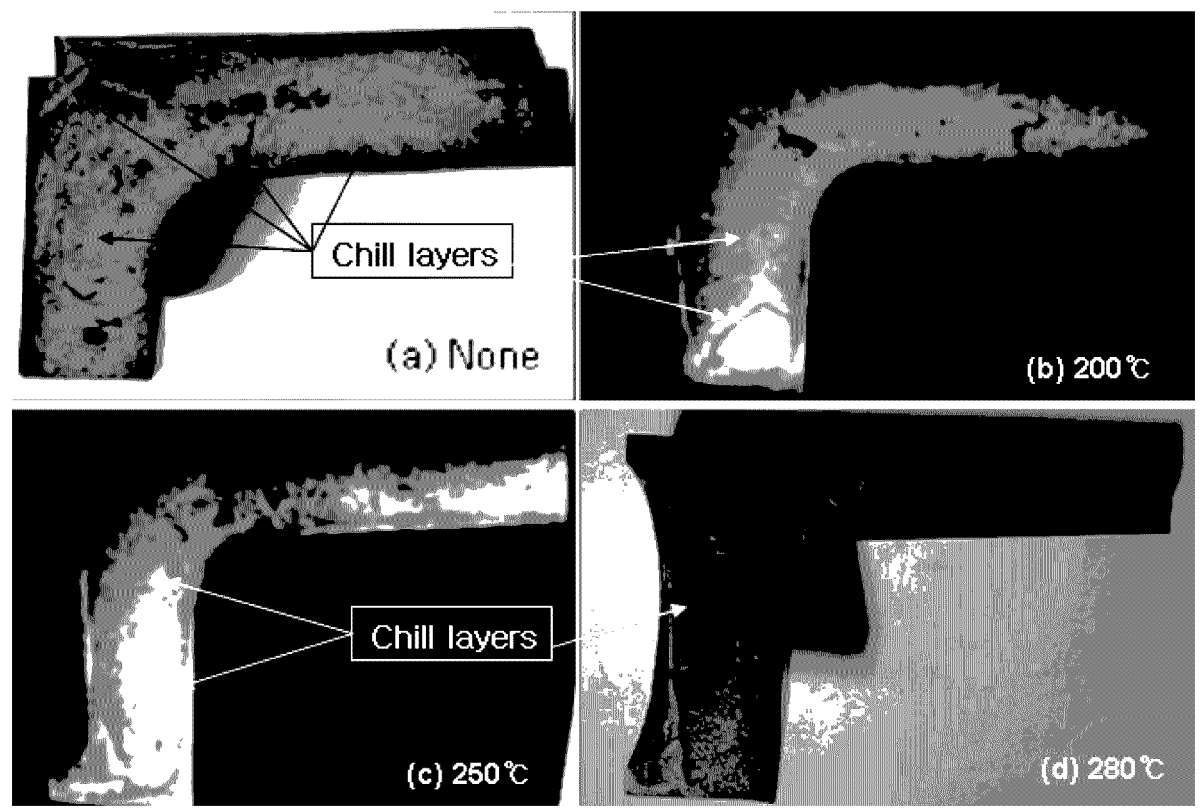

Fig. 8. Cross-sectional view of biscuits with temperature variation of shot sleeve. 

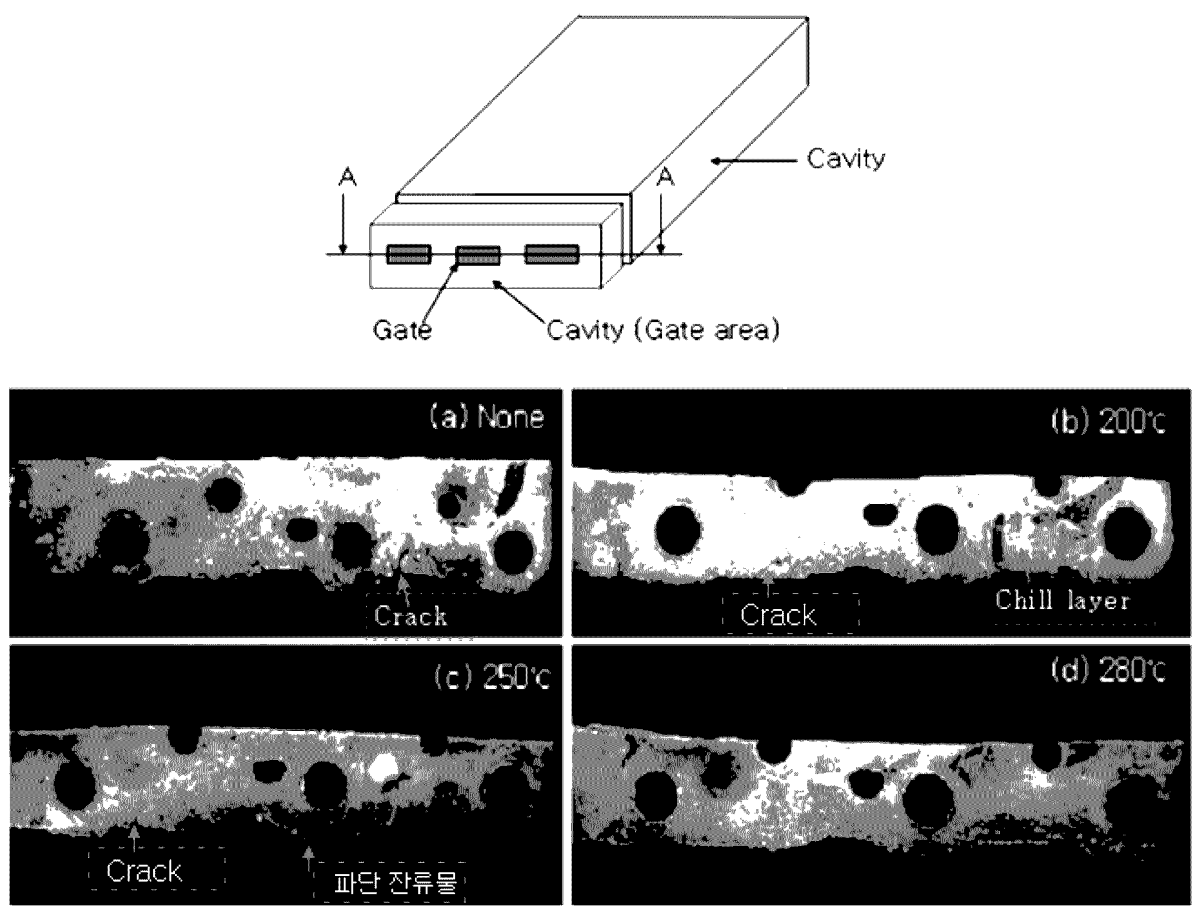

Fig. 9. Macro-morphologies of in-gate area with temperature variation of shot sleeve.

layer가 현저히 감소하여 트리밍 파단면이 균일하고 또 크 랙 발생이 없어진 것으로 여겨진다. 한편, 사출 슬리브의 온도 변화에 따른 주조품의 기공도 변화를 알아보기 위 해 충전 해석상 기포함량이 높을 것으로 예상된 제품 상 부측을 절단하여 각 조건 별로 10 개씩 샘플링 한 후 밀 도를 측정하여 Fig. 10에 평균치를 나타내었다. 슬리브 온 도 조절기를 사용하지 않은 경우에 비해 $200,250,280^{\circ} \mathrm{C}$ 로 설정 온도가 높아 질수록 평균 밀도 값이 증가하여 기 포 발생도가 감소하는 것으로 나타났으며 $280^{\circ} \mathrm{C}$ 의 경우 에서 $2.722 \mathrm{~g} / \mathrm{cm}^{3}$ 로 최대 값을 나타내었다. 특히, 슬리브 에 인위적으로 승온시킨 경우가 온도 조절기를 적용하자

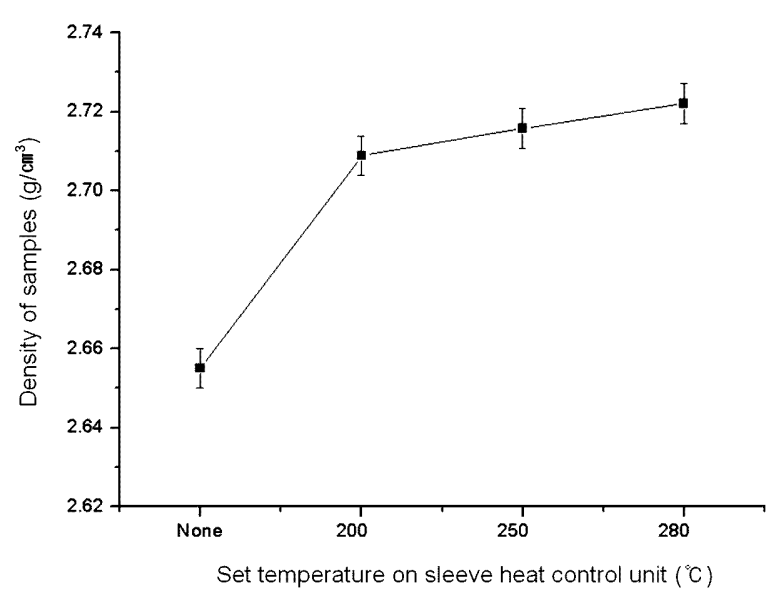

Fig. 10. Density changes of samples with the variation of set temperature on sleeve heat control unit.
않은 경우에 비해서 큰 폭의 밀도 상승이 일어났는데 이 는 슬리브 승온에 따른 chill layer의 감소로 충전시 와 류에 의한 기포 형성 가능성이 출어들었기 때문으로 판 단되며 이는 앞서 행한 chill layer에 의한 용탕 충전 거 동 방해로 전체 부품의 기포 불량 가능성이 높아진 충 전 해석결과와 잘 일치한다.

\section{4. 결 론}

알루미늄 고압 다이캐스팅에서 사출 슬리브에서 발생 하는 chill layer가 제품의 품질에 미치는 영향과 사출 슬 리브의 온도 변화에 따른 chill layer의 거동 분석을 통 해 다음과 같은 결론을 얻었다.

(1) 실 주조품의 게이트부에 형성된 chill layer를 모델 링하여 행한 충전해석 결과 용탕의 충전 양상이 chill layer가 없는 경우에 비해 불균일하고 그로 인해 기포의 발생 가능성이 상대적으로 높아지는 것으로 나타났다.

(2) 사출 슬리브 온도를 $200,250,280^{\circ} \mathrm{C}$ 로 변화시켜 가며 주조품의 비스켓 및 게이트부의 chill layer 생성량 을 분석한 결과 온도가 증가할수록 chill layer의 생성량 이 감소되었으며 $280^{\circ} \mathrm{C}$ 에서 가장 적은 chill layer가 관 찰되었고 또 트리밍 후 가장 양호한 파면을 보였다. 이 로써 사출 슬리브의 온도 조절을 통해 싸이클 타임 증 가 없이 효과적으로 chill layer를 저감할 수 있었다.

(3) 슬리브 온도를 증가하며 주조품의 밀도를 측정한 결과 슬리브 온도 조절기를 적용하지 않은 경우와 비교 


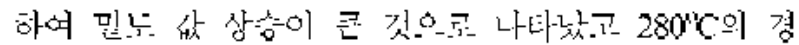
이에서 $2.722 \mathrm{~g} / \mathrm{cm}^{3}$ 고 최대 삾을 나타내있다. $280^{\circ} \mathrm{C}$ 곤 신 정한 경이에서는 제뚠국 과언고 인해 산혹 소착 년량이 반생하여 핞훙 굽형 냉차시스뎁 개선 낓 영낭 급항 온

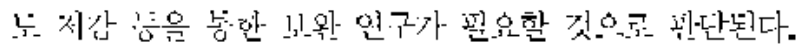

\section{감사의 글}

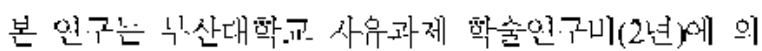
하여 이눠깄응며, 이에 찹사느ㄹㅕㅓ니다.

\section{참 고 문 헌}

1. K. Y. Kim and M. S. Yi, J. KIS. 1544h 359 (1905).

2. E. S. Kim, J. KIS. 1766h 537 (1997).

3. E. S. Kim and K. H. Los J. KIS. 23(4h 171 (2003).

4. E. Kato, A. Kohketsu and H. Nomuran J. DC Congress. JD00-27, 171 (2000).

5. S. Sartakiatist and K. Fuyjitan, J. DC Congress., JD00-28, $179(2000)$.

6. H. Kambx, M. Sayathi and T. Nakambura, J. DC Congress. JD0\%-33, $215(1008)$.

T. J. Y. Park, E. S. Kim and I. M. Park, J. KIS., 2466, 347 (2004). 